dr inż. Zbigniew Durzyński, prof. nadzw.

Instytut Pojazdów Szynowych „,TABOR”

\title{
Prawne regulacje w zakresie taboru kolejowego \\ Ocena zgodności podsystemu „TABOR” i jego sktadników interoperacyjności
}

\begin{abstract}
Artykut jest kolejnym, trzecim z cyklu pod wspólnym tytułem „Prawne regulacje w zakresie taboru kolejowego". Zawiera podstawowe informacje opracowane na podstawie różnego rodzaju dokumentów obowiqzujacych dla taboru kolejowego. Przedstawione zestawienia, omówienia i komentarze moga być pomocne w codziennej pracy specjalistów zajmujacych się badaniami oraz certyfikacja taboru kolejowego i jego głównych składników oraz $w$ pracy inżynierów $w$ zakładach produkujacych tabor.

Artykut zawiera także tzw. linki do stron internetowych, na których dostępne sq petne teksty przytoczonych i omawianych dokumentów.
\end{abstract}

\section{Tryby weryfikacji podsystemów i składników interoperacyjności}

Na wstępie należy przypomnieć dwie definicje istotne dla trybu działania.

Według art. 22 ust. $1[1]$ :

Pojazd zgodny z TSI: pojazd, który jest zgodny ze wszystkimi istotnymi TSI obowiązującymi w momencie dopuszczenia do eksploatacji, pod warunkiem, że znaczna część zasadniczych wymagań została określona w tych TSI i że odpowiednia TSI dotycząca taboru weszła w życie i ma zastosowanie,

a zgodnie $\mathrm{z}$ art. 24 ust. 1 :

Pojazd niezgodny z TSI: pojazd, które nie jest zgodny ze wszystkimi stosownymi TSI obowiązującymi w dniu dopuszczenia tego pojazdu do eksploatacji, w tym pojazdy objęte odstępstwami, lub gdy znaczna część zasadniczych wymagań nie została ujęta w jednej lub kilku TSI.

Zgodnie z podziałem pojazdów (patrz rozdz. $1.4 \mathrm{w}$ [11]) dla pojazdów niezgodnych z wszystkimi TSI

${ }^{1)}$, ustalono następujące tryby działania, które zostały opisane w dyrektywie [1], jak następuje.

Artykuł 24: Pierwsze zezwolenie na dopuszczenie do eksploatacji pojazdów niezgodnych z TSI

1. .....

2. Pierwsze zezwolenie wydaje krajowy organ ds. bezpieczeństwa w nastęujacy sposób:

- do aspektów technicznych ujętych w TSI, o ile istnieja, zastosowanie ma procedura weryfikacji $W E$,

- do pozostatych aspektów technicznych zastosowanie maja przepisy krajowe zgloszone na mocy art. 17 ust. 3 niniejszej dyrektywy oraz na mocy art. 8 dyrektywy 2004/49/WE.

Pierwsze zezwolenie jest ważne wyłacznie w obrębie sieci wydajacego je państwa członkowskiego.

Artykuł 25: Dodatkowe zezwolenia na dopuszczenie do eksploatacji pojazdów niezgodnych z TSI

1. .......

2. Wnioskodawca przedkłada krajowemu organowi ds. bezpieczeństwa dokumentacje techniczna dotyczqca pojazdu lub typu pojazdu wraz ze szczególami przewidzianego użytkowania na sieci. Dokumentacja zawiera następujace informacje:

a) udokumentowany dowód uzyskania zezwolenia na dopuszczenie pojazdu do eksploatacji $w$ innym państwie czlonkowskim i dokumentacje dotyczqca procedury zastosowanej $w$ celu wykazania, że pojazd spetniat obowiqzujace wymagania z zakresu bezpieczeństwa, $w$ tym, $w$ stosownych przypadkach, odstepstwa przyznane zgodnie z art. 9;

d) dowody zgodności charakterystyki technicznej i eksploatacyjnej pojazdu z infrastruktura $i$ statymi instalacjami, w tym klimatyzacja, systemem zasilania w energie, systemem sterowania ruchem kolejowym, prześwitem toru i skrajniami infrastruktury, maksymalnym dopuszczalnym obciażeniem osi i innymi ograniczeniami sieci.

1) Ze względu na brak aktualnie w kraju możliwości weryfikacji WE pojazdu pod kątem zgodności z systemami ETCS autor ograniczył się do pojazdów niezgodnych z TSI. 
Procedura dla pojazdów niezgodnych z TSI w Ustawie o transporcie kolejowym [9] jest następująca (do porównania $z$ ww. art. 24):

Art. 23b. (wybrane ustepy)

1a. Pojazdy kolejowe niezgodne z TSI podlegaja weryfikacji obejmujacej badania:

1) zgodności z krajowymi specyfikacjami technicznymi i dokumentami normalizacyjnymi określonymi $w$ przepisach wydanych na podstawie art. $25 t$,

2) zgodności z sieciq kolejowa, w szczególności w zakresie zgodności charakterystyki technicznej $i$ eksploatacyjnej pojazdu kolejowego z infrastrukturq i statymi instalacjami,

3) parametrów określonych w przepisach wydanych na podstawie art. 25ta ust. 1

- przeprowadzane przez podmioty uprawnione do przeprowadzania badań niezbędnych do dopuszczenia do eksploatacji pojazdów kolejowych niezgodnych z TSI, o których mowa w przepisach wydanych na podstawie art. 25ta ust. 1 pkt 8.

3. $Z$ wnioskiem o wydanie zezwolenia na dopuszczenie do eksploatacji pojazdu kolejowego zgodnego z TSI występuje zarzqdca, przewoźnik kolejowy, dysponent, producent, wykonawca modernizacji albo importer, załaczając dokumenty określone w art. 23e ust. 1.

6. Z wnioskiem o wydanie zezwolenia na dopuszczenie do eksploatacji pojazdu kolejowego niezgodnego z TSI obowiazujacymi $w$ dniu dopuszczania pojazdu kolejowego, $w$ tym pojazdu kolejowego objętego odstępstwami, wystęuje zarzadca, przewoźnik kolejowy, dysponent, producent, wykonawca modernizacji albo importer, załaczajac dokumenty określone w art. 23e ust. 2. Dopuszczenie to uprawnia do poruszania się na sieci kolejowej polożonej na terytorium Rzeczypospolitej Polskiej.

Art. 23e.

1. Do wniosku, o którym mowa w art. 23 b ust. 3, załacza się:

1) deklaracje weryfikacji WE podsystemu dla wszystkich podsystemów strukturalnych pojazdu kolejowego, jeżeli wszystkie podsystemy strukturalne pojazdu kolejowego uzyskaty zezwolenie na dopuszczenie do eksploatacji zgodnie z postanowieniami rozdziatu $4 a$ w zakresie dopuszczania podsystemów do eksploatacji;

2) wszystkie deklaracje weryfikacji WE podsystemu, które potwierdzaja:

a) zgodność podsystemów pojazdu kolejowego z TSI i ich bezpieczne zamontowanie,

b) zgodność pojazdu kolejowego z sieciq kolejowa, w tym dokumenty potwierdzajace zgodność charakterystyki technicznej i eksploatacyjnej pojazdu kolejowego z infrastruktura $i$ statymi instalacjami,

c) zgodność pojazdu kolejowego z przepisami wydanymi na podstawie art. 25t, majacymi zastosowanie do punktów otwartych i szczególnych przypadków określonych w TSI.

2. Do wniosku, o którym mowa w art. 23 b ust. 6, zatacza się:

1) dla podsystemów zgodnych z TSI obowiqzujacymi $w$ dniu wydania zezwolenia na dopuszczenie do eksploatacji pojazdu kolejowego dokumenty, o których mowa w ust. 1 pkt 2;

2) dla podsystemów niezgodnych z którakolwiek z TSI obowiazujacych $w$ dniu wydania zezwolenia na dopuszczenie do eksploatacji pojazdu kolejowego dokumenty potwierdzajace:

a) zgodność podsystemów pojazdu kolejowego z przepisami wydanymi na podstawie art. 25t,

b) zgodność pojazdu kolejowego z siecia kolejowa, w tym dokumenty potwierdzajace zgodność charakterystyki technicznej i eksploatacyjnej pojazdu kolejowego z infrastrukturq $i$ statymi instalacjami,

c) pozytywne wyniki kontroli parametrów pojazdu kolejowego określonych w przepisach wydanych na podstawie art. 25ta ust. 1 ;

3) certyfikat weryfikacji pojazdu kolejowego niezgodnego z TSI;

4) deklarację weryfikacji pojazdu kolejowego niezgodnego z TSI.

Po opublikowaniu dyrektywy [1] w kolejnych latach zostały zmienione niektóre załączniki do niej:

Zat. II: Zakres stosowania

Zat. III: Podsystemy

Zat. V: Deklaracja weryfikacji WE podsystemów

Zat. VI: Procedura weryfikacyjna WE dla podsystemów

Zat. VII: Parametry do skontrolowania w celu dopuszczenia do eksploatacji pojazdów niezgodnych z TSI oraz klasyfikacja przepisów krajowych. 
Należy mieć na uwadze różne okresy przejściowe związane z oceną składników interoperacyjności w ramach weryfikacji WE podsystemu, które w [2] w art. 8 zostały opisane następująco:

1. Świadectwa weryfikacji WE podsystemu zawierajacego sktadniki interoperacyjności nieposiadajace deklaracji WE zgodności lub przydatności do stosowania moga być wydawane w czasie sześcioletniego okresu przejściowego kończqcego się $w$ dniu 31 maja 2017 r., o ile spetniono wymagania przepisów określonych w pkt 6.3 zatacznika.

podczas gdy w [3] w art. 8 okres przejściowy dla jest inny:

1. Świadectwa weryfikacji WE dla podsystemu zawierajacego składniki interoperacyjności bez deklaracji WE o zgodności lub przydatności do stosowania moga być wydawane $w$ czasie trwania okresu przejściowego wynoszqcego dziesięć lat od wejścia w życie niniejszego rozporzadzenia ${ }^{2)}$, o ile spetnione sq przepisy określone w pkt 6.3 załqcznika.

Link do tekstu ww. dyrektywy jest następujący:

http://www.utk.gov.pl/pl/wymagania-wspolnotowe/prawo-wspolnotowe/128,Dyrektywy-

Rozporzadzenia-i-Decyzje.html,

natomiast do tekstów TSI:

http://www.utk.gov.pl/pl/wymagania-wspolnotowe/prawo-wspolnotowe/430,Techniczne-Specyfikacjedla-Interoperacyjnosci.html

\section{Moduły stosowane w procedurach oceny}

Uzyskanie certyfikatu dla składnika interoperacyjności wymaga przeprowadzenia odpowiedniej procedury wg ustalonych modułów opisanych szczegółowo w [8].

\begin{tabular}{l|l}
\multicolumn{1}{c}{ Moduly stosowane do wydania świadectwa WE o zgodności składników interoperacyjności } \\
\hline Moduł CA & \multicolumn{1}{c}{ Wewnętrzna kontrola produkcji } \\
\hline Moduł CA1 & $\begin{array}{l}\text { Wewnętrzna kontrola produkcji plus sprawdzenie produktu w trakcie badania jedno- } \\
\text { stkowego }\end{array}$ \\
\hline Moduł CA2 & $\begin{array}{l}\text { Wyrywkowa kontrola wewnętrzna produkcji plus sprawdzenie produktu w losowo } \\
\text { wybranych odstępach czasu }\end{array}$ \\
\hline Moduł CB & Badanie typu WE \\
\hline Moduł CC & Zgodność z typem na podstawie wewnętrznej kontroli produkcji \\
\hline Moduł CD & $\begin{array}{l}\text { Zgodność z typem na podstawie systemu zarządzania jakością w procesie produk- } \\
\text { cyjnym }\end{array}$ \\
\hline Moduł CF & Zgodność z typem na podstawie systemu sprawdzenia produktu \\
\hline Moduł CH & Zgodność ustalana w oparciu o pełny system zarządzania jakością \\
\hline Moduł CH1 & Zgodność w oparciu o pełny system zarządzania jakością plus badanie projektu \\
\hline Moduł CV & Walidacja typu poprzez badanie eksploatacyjne (przydatność do stosowania) \\
\hline
\end{tabular}

Producent lub jego upoważniony przedstawiciel dokonuje wyboru jednego z modułów lub kombinacji modułów wskazanych w poniższej tabeli, w zależności od wymaganego składnika interoperacyjności (wg. [2]).

W przypadku następujących składników interoperacyjności wymaga się oceny przydatności do stosowania zgodnie z procedurą walidacji typu poprzez badanie eksploatacyjne (moduł CV):

— koła,

— zabezpieczenie przeciwpoślizgowe kół.

Przed rozpoczęciem badań eksploatacyjnych należy zastosować odpowiedni moduł (CB lub $\mathrm{CH})$ w celu certyfikowania konstrukcji danego składnika.

Według [3], dla wagonów towarowych, możliwe jest stosowanie poniższych modułów. 


\begin{tabular}{|c|c|c|c|c|c|c|c|c|}
\hline Punkt & $\begin{array}{c}\text { Składniki } \\
\text { poddawane ocenie }\end{array}$ & $\begin{array}{c}\text { Modul } \\
\text { CA }\end{array}$ & $\begin{array}{l}\text { Moduł } \\
\text { CA1 lub } \\
\text { CA2 }\end{array}$ & $\begin{array}{c}\text { Moduł } \\
\mathrm{CB}+\mathrm{CC}\end{array}$ & $\begin{array}{l}\text { Moduł } \\
\text { CB }+ \\
C D\end{array}$ & $\begin{array}{l}\text { Modul } \\
\mathrm{CB}+\mathrm{CF}\end{array}$ & $\underset{\mathrm{CH}}{\text { Modul }}$ & $\begin{array}{c}\text { Moduł } \\
\mathrm{CH} 1\end{array}$ \\
\hline 5.3 .1 & $\begin{array}{l}\text { Samoczynny } \\
\text { centralny } \\
\text { zderzak-sprzegg }\end{array}$ & & $\mathrm{X}\left({ }^{*}\right)$ & & $\mathrm{x}$ & $\mathrm{x}$ & $X\left(*^{*}\right)$ & $\mathrm{x}$ \\
\hline 5.3 .2 & $\begin{array}{l}\text { Ręczny sprzęg } \\
\text { końcowy }\end{array}$ & & $X(*)$ & & $\mathrm{x}$ & $\mathrm{x}$ & $X\left(*^{*}\right)$ & $\mathrm{x}$ \\
\hline 5.3 .3 & $\begin{array}{l}\text { Sprzegg holow- } \\
\text { niczy do akcji } \\
\text { ratowniczych }\end{array}$ & & $\mathrm{X}\left({ }^{*}\right)$ & & $\mathrm{x}$ & $\mathrm{x}$ & $X\left(*^{*}\right)$ & $\mathrm{x}$ \\
\hline 5.3 .4 & Koło & & $X\left(*^{*}\right)$ & & $\mathrm{x}$ & $\mathrm{x}$ & $X\left(*^{*}\right)$ & $\mathrm{x}$ \\
\hline 5.3 .5 & $\begin{array}{l}\text { Zabezpieczenie } \\
\text { przed poślizgiem } \\
\text { kół }\end{array}$ & & $X\left(*^{*}\right)$ & & $\mathrm{x}$ & $\mathrm{x}$ & $X\left({ }^{*}\right)$ & $\mathrm{x}$ \\
\hline 5.3 .6 & Światlo czolowe & & $X\left(\left(^{*}\right)\right.$ & $\mathrm{x}$ & $\mathrm{x}$ & & $X\left({ }^{*}\right)$ & $\mathrm{x}$ \\
\hline 5.3 .7 & $\begin{array}{l}\text { Światlo sygna- } \\
\text { lowe }\end{array}$ & & $X\left({ }^{*}\right)$ & $\mathrm{x}$ & $\mathrm{x}$ & & $X\left({ }^{*}\right)$ & $\mathrm{x}$ \\
\hline 5.3 .8 & $\begin{array}{l}\text { Światto końca } \\
\text { pociągu }\end{array}$ & & $\mathrm{X}\left({ }^{*}\right)$ & $\mathrm{x}$ & $\mathrm{x}$ & & $\mathrm{X}\left({ }^{*}\right)$ & $\mathrm{x}$ \\
\hline 5.3 .9 & $\begin{array}{l}\text { Sygnaly dźwię- } \\
\text { kowe }\end{array}$ & & $\mathrm{X}\left({ }^{*}\right)$ & $\mathrm{x}$ & $\mathrm{x}$ & & $X\left(*^{*}\right)$ & $\mathrm{X}$ \\
\hline 5.3 .10 & Pantograf & & $\mathrm{X}\left({ }^{*}\right)$ & & $\mathrm{x}$ & $\mathrm{x}$ & $\mathrm{X}\left({ }^{*}\right)$ & $\mathrm{x}$ \\
\hline 5.3 .11 & $\begin{array}{l}\text { Nakładki stykowe } \\
\text { pantografu }\end{array}$ & & $\mathrm{X}\left({ }^{*}\right)$ & & $\mathrm{x}$ & $\mathrm{x}$ & $X\left(*^{*}\right)$ & $\mathrm{x}$ \\
\hline
\end{tabular}

\begin{tabular}{c|l|c|c|c|c|c|c|c}
\hline Punkt & $\begin{array}{c}\text { Składniki } \\
\text { poddawane ocenie }\end{array}$ & $\begin{array}{c}\text { Moduł } \\
\mathrm{CA}\end{array}$ & $\begin{array}{c}\text { Moduł } \\
\mathrm{CA} 1 \text { lub } \\
\mathrm{CA} 2\end{array}$ & $\begin{array}{c}\text { Moduł } \\
\mathrm{CB}+\mathrm{CC}\end{array}$ & $\begin{array}{c}\text { Moduł } \\
\mathrm{CB}+ \\
\mathrm{CD}\end{array}$ & $\begin{array}{c}\text { Moduł } \\
\mathrm{CB}+\mathrm{CF}\end{array}$ & $\begin{array}{c}\text { Moduł } \\
\mathrm{CH}\end{array}$ & $\begin{array}{c}\text { Moduł } \\
\mathrm{CH} 1\end{array}$ \\
\hline 5.3 .12 & $\begin{array}{l}\text { Wylącznik } \\
\text { glówny }\end{array}$ & $\mathrm{X}\left(^{*}\right)$ & & $\mathrm{X}$ & $\mathrm{X}$ & $\mathrm{X}\left({ }^{*}\right)$ & $\mathrm{X}$ \\
\hline 5.3 .13 & Fotel maszynisty & & $\mathrm{X}\left({ }^{*}\right)$ & & $\mathrm{X}$ & $\mathrm{X}$ & $\mathrm{X}\left({ }^{*}\right)$ & $\mathrm{X}$ \\
\hline 5.3 .14 & $\begin{array}{l}\text { Przylączenie } \\
\text { systemu opró- } \\
\text { zniania toalet }\end{array}$ & $\mathrm{X}$ & & $\mathrm{X}$ & & & $\mathrm{X}$ & \\
\hline 5.3 .15 & $\begin{array}{l}\text { Przylącze } \\
\text { wlotowe do } \\
\text { napetniania } \\
\text { zbiorników wody }\end{array}$ & $\mathrm{X}$ & & $\mathrm{X}$ & & & $\mathrm{X}$ & \\
\hline
\end{tabular}

\begin{tabular}{c|l|c|c|c|c|c}
\hline \multirow{2}{*}{ Punkt } & \multicolumn{1}{|c|}{ Składnik } & \multicolumn{4}{c}{ Moduły } \\
\cline { 3 - 7 } & & $\begin{array}{c}\text { CA1 lub } \\
\text { CA2 }\end{array}$ & CB + CD & CB + CF & CH & CH1 \\
\hline 4.2 .3 .6 .1 & Układ biegowy & & $\mathrm{X}$ & $\mathrm{X}$ & & $\mathrm{X}$ \\
\cline { 3 - 7 } & Układ biegowy - ustalony & $\mathrm{X}$ & & & $\mathrm{X}$ & \\
\hline 4.2 .3 .6 .2 & Zestaw kołowy & $\mathrm{X}\left({ }^{*}\right)$ & $\mathrm{X}$ & $\mathrm{X}$ & $\mathrm{X}\left({ }^{*}\right)$ & $\mathrm{X}$ \\
\hline 4.2 .3 .6 .3 & Koło & $\mathrm{X}\left({ }^{*}\right)$ & $\mathrm{X}$ & $\mathrm{X}$ & $\mathrm{X}\left({ }^{*}\right)$ & $\mathrm{X}$ \\
\hline 4.2 .3 .6 .4 & Oś & $\mathrm{X}\left({ }^{*}\right)$ & $\mathrm{X}$ & $\mathrm{X}$ & $\mathrm{X}\left({ }^{*}\right)$ & $\mathrm{X}$ \\
\hline 5.3 .5 & $\begin{array}{l}\text { Oznaczenie sygnałowe końca } \\
\text { pociaggu }\end{array}$ & $\mathrm{X}$ & & & $\mathrm{X}$ & \\
\hline
\end{tabular}

(*) Moduly CA1, CA2 lub CH można stosować wytacznie w przypadku produktów wprowadzonych do obrotu, a więc opracowanych przed wejściem niniejszej TSI $w$ życie pod warunkiem, że producent wykaże przed jednostka notyfikowana, że do celów poprzednich zastosowań dokonano przegladu konstrukcji i przeprowadzono badanie typu w porównywalnych warunkach $i$ ze sa one zgodne z wymaganiami niniejszej TSI; potwierdzenie tego faktu jest udokumentowane i jest uznane za zapewniajace ten sam poziom dowodowy jak modut CB lub badanie konstrukcji zgodnie z modutem $\mathrm{CH}$.

Wnioskodawca powinien wybrać jedną z następujących kombinacji modułów: (SB + SD) lub (SB + SF) lub (SH1) dla każdego odnośnego podsystemu (lub części podsystemu). Następnie dokonuje się oceny zgodnie z wybraną kombinacją modułów. Moduł SG wymieniony jest tylko w poniższej tablicy, brak go natomiast w dalszej treści TSI.

Poniżej, na podstawie pkt. 6.2.2 w [2] przedstawione zostały moduły, według których przeprowadza się weryfikację podsystemów kolei. 


\begin{tabular}{l|l}
\hline \multicolumn{1}{c|}{ Moduł SB } & \multicolumn{1}{|c}{ Badanie typu WE } \\
\hline Moduł SD & $\begin{array}{l}\text { Weryfikacja WE w oparciu o system zarządzania jakością w ramach procesu } \\
\text { produkcji }\end{array}$ \\
\hline Moduł SF & Weryfikacja WE w oparciu o weryfikację produktu \\
\hline Moduł SH1 & $\begin{array}{l}\text { Weryfikacja WE w oparciu o pełny system zarządzania jakością oraz badanie } \\
\text { projektu }\end{array}$ \\
\hline
\end{tabular}

Wnioskodawca wybiera jednq z następujacych kombinacji modutów: (SB+SD), (SB+SF) lub (SH1) dla każdego danego podsystemu (lub części podsystemu). Następnie należy dokonać oceny zgodnie z wybrana kombinacja modutów.

Moduły, według których dokonuje się weryfikacji pojazdów niezgodnych z TSI opisane są następująco w zał. nr. 3 [7], którego tytuły i treść głównych punktów przedstawiono poniżej.

I. Warunki i tryb dokonywania weryfikacji

II. Procedury weryfikacji zgodności

1. Badanie typu-Modut A

1.1. Badanie typu jest procedura, poprzez która podmiot wyznaczony sprawdza i poświadcza, że pojazd kolejowy reprezentatywny dla przewidywanej produkcji, zwany dalej „typem", spetnia wymagania określone w przepisach wydanych na podstawie art. 25t ustawy.

1.2. Wnioskodawca składa do wybranego przez siebie podmiotu wyznaczonego wniosek o przeprowadzenie badania typu.

2. Zapewnienie jakości produkcji - Modut B

2.1. Zapewnienie jakości produkcji jest procedura, poprzez która wnioskodawca zapewnia i deklaruje, że pojazd kolejowy jest zgodny z typem opisanym $w$ certyfikacie badania typu $i$ spetnia wymagania, które dotyczq tego pojazdu kolejowego, określone w niniejszym rozporzqdzeniu.

2.2. Producent powinien posiadać zatwierdzony system jakości w zakresie produkcji, kontroli końcowej $i$ badań, o których mowa w pkt 2.3, oraz podlegać nadzorowi, o którym mowa w pkt 2.3.13.

Wykaz parametrów pojazdu kolejowego do skontrolowania w celu dopuszczenia do eksploatacji pojazdów kolejowych niezgodnych z TSI przedstawiony jest w zał. $\mathrm{nr} 4$. do ww. rozporządzenia.

I. Dokumentacja ogólna z uwzględnieniem opisu nowego, odnowionego lub zmodernizowanego pojazdu i jego przeznaczenia, projektu, napraw, informacji dotyczacych eksploatacji i utrzymania, dokumentacji technicznej

II. Konstrukcja i części mechaniczne

III. Współdziałanie pojazdu z torem i zagadnienia skrajni

IV. Urzadzenia hamowania

V. Kwestie dotyczqce pasażerów

VI. Warunki środowiskowe i skutki dziatania sit aerodynamicznych, interfejs między pojazdem a częścia przytorowa systemu kolei i interfejs między pojazdem a otoczeniem

VII. Wymogi w zakresie zewnętrznych systemów ostrzegania, oznakowania, funkcji i integralności oprogramowania oraz magistrala komunikacyjna pociagu

VIII. Pokładowe systemy napędu, zasilania i sterowania, aspekty kompatybilności elektromagnetycznej oraz rejestratory parametrów jazdy

IX. Urzadzenia dla personelu, interfejsy $i$ środowisko

X. Bezpieczeństwo przeciwpożarowe i ewakuacja

XI. Obstuga: $w$ tym urzadzenia poktadowe i interfejsy

XII. Pokładowe urzqdzenia bezpiecznej kontroli jazdy pociagu i pokładowe urzqdzenia sterowania ruchem kolejowym

XIII. Wymogi eksploatacyjne, w tym przywracania sprawności pojazdu

$X I V$. Kwestie dotyczqce tadunków.

\section{Zakres badań pojazdów i składników interoperacyjności}

Poniżej przedstawiono fragment wymagań (przykładowo dotyczących konstrukcji i części mechanicznej) dla pojazdu interoperacyjnego, podlegających ocenie. Łącznie kolumna 3 „Badanie typu” obejmuje kilkadziesiąt pozycji, w związku z czym dla ilustracji przytoczono tylko fragment dodatku $\mathrm{H}$ do [2]: 


\begin{tabular}{|c|c|c|c|c|c|}
\hline \multicolumn{2}{|l|}{1} & 2 & 3 & 4 & 5 \\
\hline \multirow{2}{*}{\multicolumn{2}{|c|}{$\begin{array}{c}\text { Whaściwości podlegające ocenie, jak określono w pkt } 4.2 \\
\text { niniejszej TSI }\end{array}$}} & \multicolumn{2}{|c|}{ Etap projektowania i rozwoju } & $\begin{array}{l}\text { Etap } \\
\text { produkcji }\end{array}$ & \multirow{2}{*}{$\begin{array}{l}\text { Szczególna } \\
\text { procedura } \\
\text { oceny }\end{array}$} \\
\hline & & Przegląd & Badanie typu & Badanie & \\
\hline Element podsystemu „Tabor” & Punkt & & & & Punkt \\
\hline Konstrukcja i części mechaniczne & 4.2.2 & & & & \\
\hline Sprzęg wewnętrzny & 4.2 .2 .2 .2 & $\mathrm{x}$ & nd. & nd. & - \\
\hline Sprzęg końcowy & 4.2 .2 .2 .3 & $\mathrm{x}$ & nd. & nd. & - \\
\hline $\begin{array}{l}\text { Składnik interoperacyjności: samo- } \\
\text { czynny centralny zderzak-sprzęg }\end{array}$ & 5.3 .1 & $\mathrm{x}$ & $\mathrm{x}$ & $\mathrm{x}$ & - \\
\hline $\begin{array}{l}\text { Składnik interoperacyjności: ręczny } \\
\text { sprzęg końcowy }\end{array}$ & 5.3 .2 & $\mathrm{x}$ & $\mathrm{x}$ & $\mathrm{X}$ & - \\
\hline Sprzęg ratunkowy & 4.2 .2 .2 .4 & $\mathrm{X}$ & $\mathrm{x}$ & nd. & - \\
\hline $\begin{array}{l}\text { Składnik interoperacyjności: sprzęg } \\
\text { ratunkowy }\end{array}$ & 5.3 .3 & $\mathrm{X}$ & $\mathrm{x}$ & $\mathrm{X}$ & \\
\hline $\begin{array}{l}\text { Dostęp dla personelu do sprzęgania/ } \\
\text { rozprzęgania }\end{array}$ & 4.2 .2 .2 .5 & $\mathrm{x}$ & $\mathrm{x}$ & nd. & - \\
\hline Przejścia międzywagonowe & 4.2 .2 .3 & $\mathrm{x}$ & $\mathrm{x}$ & nd. & - \\
\hline Wytrzymałość konstrukcji pojazdu & 4.2.2.4 & $\mathrm{x}$ & $\mathrm{x}$ & nd. & - \\
\hline
\end{tabular}

oraz fragment dodatku $\mathrm{F}$ do [3] przedstawia elementy konstrukcji wagonu podlegające ocenie:

\begin{tabular}{|c|c|c|c|c|c|}
\hline \multirow{2}{*}{\multicolumn{2}{|c|}{ Charakterystyka podlegająca ocenie, jak określono w sekcji 4.2}} & \multicolumn{2}{|c|}{$\begin{array}{c}\text { Faza projektowania i } \\
\text { opracowania }\end{array}$} & \multirow{3}{*}{$\begin{array}{c}\begin{array}{c}\text { Faza } \\
\text { produkcji }\end{array} \\
\begin{array}{c}\text { Badanie } \\
\text { rutynowe }\end{array}\end{array}$} & \multirow{3}{*}{$\begin{array}{l}\begin{array}{c}\text { Szczególne procedury } \\
\text { oceny }\end{array} \\
\text { Punkt }\end{array}$} \\
\hline & & \multirow{2}{*}{$\begin{array}{c}\text { Przeglaad } \\
\text { konstrukcji }\end{array}$} & \multirow{2}{*}{$\begin{array}{c}\text { Badanie } \\
\text { typu }\end{array}$} & & \\
\hline Element podsystemu „Tabor" & Punkt & & & & \\
\hline Konstrukcja oraz części mechaniczne & 4.2 .2 & & & & \\
\hline Sprzegg końcowy & 4.2.2.1.1 & $\mathrm{x}$ & $\begin{array}{l}\text { nie doty- } \\
\text { czy }\end{array}$ & $\begin{array}{l}\text { nie doty- } \\
\text { czy }\end{array}$ & - \\
\hline Sprzegg wewnętrzny & 4.2.2.1.2 & $\mathrm{x}$ & $\begin{array}{l}\text { nie doty- } \\
\text { czy }\end{array}$ & $\begin{array}{l}\text { nie doty- } \\
\text { czy }\end{array}$ & - \\
\hline Wytrzymałość jednostki & 4.2 .2 .2 & $\mathrm{x}$ & $\mathrm{x}$ & $\begin{array}{l}\text { nie doty- } \\
\quad \text { czy }\end{array}$ & 6.2 .2 .1 \\
\hline Integralność jednostki & 4.2 .2 .3 & $\mathrm{x}$ & $\begin{array}{l}\text { nie doty- } \\
\text { czy }\end{array}$ & $\begin{array}{l}\text { nie doty- } \\
\text { czy }\end{array}$ & - \\
\hline $\begin{array}{l}\text { Wspóldziałanie pojazdu z torem i pomiary } \\
\text { kontrolne }\end{array}$ & 4.2 .3 & & & & \\
\hline Skrainia & 4.2 .3 .1 & $\mathrm{x}$ & $\begin{array}{l}\text { nie doty- } \\
\text { czy }\end{array}$ & $\begin{array}{l}\text { nie doty- } \\
\text { czy }\end{array}$ & - \\
\hline Zgodność z obcią̧alnością linii & 4.2 .3 .2 & $\mathrm{x}$ & $\mathrm{x}$ & $\begin{array}{l}\text { nie doty- } \\
\text { czy }\end{array}$ & - \\
\hline Zgodność z systemami detekcji pociagów & 4.2 .3 .3 & $\mathrm{x}$ & $\mathrm{x}$ & $\begin{array}{l}\text { nie doty- } \\
\quad \text { czy }\end{array}$ & - \\
\hline Monitorowanie stanu łożysk osi & 4.2 .3 .4 & $\mathrm{x}$ & $\mathrm{x}$ & $\begin{array}{l}\text { nie doty- } \\
\text { czy }\end{array}$ & - \\
\hline
\end{tabular}

Szczegółowe wymagania zawarte są w punktach podanych w kolumnach 1, bezpośrednio w tekście [2, 3] lub w przywołanych normach. Zawierają one szczegółowe wymagania dotyczące szeroko rozumianych badań i weryfikacji WE zgodności pojazdów trakcyjnych i pasażerskich. Poniżej zestawiono te normy

\footnotetext{
1. $\quad E N 12663-1: 2010$

2. EN $13103: 2009$

3. EN $13104: 2009$

4. EN $13260: 2009$

5. EN 13306

6. EN $1363-1: 1999$

7. EN $13674-1: 2003$

8. EN $13674-1: 2003 / \mathrm{A} 1: 2007$

9. EN $13715: 2006$

10. EN $13749: 2005$

11. EN 13848 - 1

12. EN $13848-1: 2003 / \mathrm{A} 1: 2008$

13. EN $13979-1: 2003$

14. EN 13979 - $1: 2003 / A 1: 2009$

15. EN $14067-4: 2005 / \mathrm{A} 1: 2009$

16. EN $14198: 2004$
}

$\begin{array}{ll}\text { 17. } & \text { EN } 14363: 2005 \\ \text { 18. } & \text { EN } 14531-1: \mathbf{2 0 0 5} \\ \text { 19. } & \text { EN } 14531-6: 2009 \\ \text { 20. } & \text { EN } 15152: 2007 \\ \text { 21. } & \text { EN } 15153-1: 2007 \\ \text { 22. } & \text { EN } 15153-2: 2007, \\ \text { 23. } & \text { EN } 15227: 2008 \\ \text { 24. } & \text { EN 15273 }-2: \mathbf{2 0 0 9} \\ \text { 25. } & \text { EN } 15302: 2008 \\ \text { 26. } & \text { EN 15437 }-\mathbf{1}: 2009 \\ \text { 27. } & \text { EN } 15551: 2009 \\ \text { 28. } & \text { EN 15566 }: 2009 \\ \text { 29. } & \text { EN 15595:2009 } \\ \text { 30. } & \text { EN } 15686: 2010 \\ \text { 31. } & \text { EN } 45545-2 \\ \text { 32. } & \text { EN } 50119: 2009\end{array}$

18. EN $14531-1: 2005$

33. EN $50125-1: 1999$

34. EN $50153: 2002$

35. EN $50206-1: 2010$

36. EN $50317: 2002$

37. EN $50318: 2002$

38. EN $50367: 2006$

39. EN $50388: 2005$

40. EN $50405: 2006$

41. EN $60721-3-5$ :

1997

42. CSM

43. UIC $541-1$

44. UIC $541-06$

45. UIC 627 - 2

46. UIC 648

47. UIC 651 
Pozycje wyróżnione (wytłuszczona kursywa) dotyczą norm przywołanych w specyfikacji dla wagonów towarowych [3], w której ponadto podane są niżej zestawione normy.

1. Dokument techniczny Agencji ERA/TD/201204/INT wersja $1.0 \mathrm{z}$ dnia 4.6.2012

2. EN 12082:2007+ A1:2010

3. EN 13262: $2004+\mathrm{A} 1: 2008$ $+\mathrm{A} 2: 2011$

4. EN 13501-1:2007+ A1:2009

5. EN 14601:2005+ A1:2010

6. EN 15085-1-5:2007

7. EN $15355: 2008+\mathrm{A} 1: 2010$

8. EN 15528:2008EN 15551:2009 + A1:2010

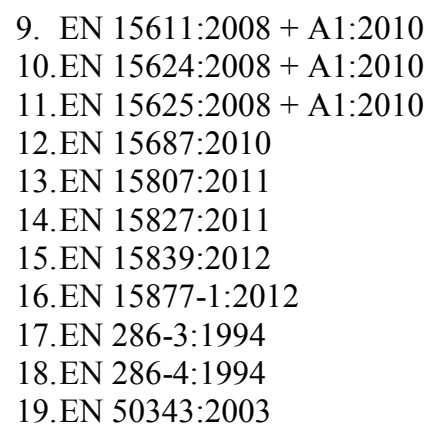

20.EN 50355:2003

21.ISO 5658-2:2006/A1:2011

22.Pr EN 16235

23.TS 45545-7:2009

24.UIC 430-1:2006

25.UIC 430-3:1995

26.UIC 535-2:2006

27.UIC 540:2006

28.UIC 541-1:2010

29.UIC 542:2010

30.UIC 575:1995

Należy zwrócić uwagę na istotne różnice między liczbą norm przywołanych w TSI [2, 3] i rozporządzeniu krajowym [6], zwłaszcza dotyczących składników interoperacyjności. Przykładowo dla koła i zestawu kołowego wymagania te są określone w poz. 27 i 28 załącznika $\mathrm{nr} 1$ do ww. rozporządzenia. Normy dotyczące tych elementów wymienione w TSI [2] zaznaczono na czerwono.

\begin{tabular}{|c|c|c|}
\hline 27. & Zestaw kołowy (oś + koła) & $\begin{array}{l}\text { PN-EN 12080, PN-EN 12081, PN-EN 12082, PN-EN 13103, PN-EN 13104, } \\
\text { PN-EN 13260, PN-EN 13261, PN-EN 13262, PN-EN 13715, PN-EN 13979-1, } \\
\text { PN-EN 15313, UIC/OSJD 430-4, UIC/OSJD 430-5, UIC 510-5, UIC 510-4, } \\
\text { UIC 512, UIC 515-5, PN-K-91018, PN-K-91019, PN-K-91020, PN-K-91032, } \\
\text { PN-K-91034, PN-K-91035, PN-K-91041, PN-K-91042, PN-K-91043, PN-K-91045, } \\
\text { PN-K-91046, PN-K-91047, PN-K-91048, PN-K-91049, TS 13979-2, TS } 15718\end{array}$ \\
\hline 28. & Koło & $\begin{array}{l}\text { PN-EN 13262, PN-EN 13715, PN-EN 13979-1, UIC 510-2, UIC 510-5, UIC 810-1, } \\
\text { UIC } 810-2 \text {, UIC 810-3, UIC 812-1, UIC 812-4, UIC 812-5, PN-K-91018, } \\
\text { PN-K-91019, PN-K-91020, PN-K-91032, PN-K-91033, PN-K-91034, PN-K-91035, } \\
\text { PN-K-91041, PN-K-91042, PN-K-91043, PN-K-91045, PN-K-91049, TS 13979-2, } \\
\text { TS } 15718\end{array}$ \\
\hline
\end{tabular}

Pełna lista składników interoperacyjności zawarta jest w zał. nr 1 do [7]. Poniżej przytoczone zostały niektóre składniki dla kolei konwencjonalnej.

\section{Dla systemu kolei konwencjonalnych:}

4. Podsystem sterowanie:

4.1. należace do podsystemu sterowanie - urzadzenia pokładowe:

4.1.1. poktadowy ERTMS/ETCS,

4.1.2. urzadzenia odometryczne,

4.1.3. interfejs zewnętrznego STM,

4.1.4. radiotelefon kabinowy $G S M-R$,

4.1.5. radio GSM-R na potrzeby transmisji danych ETCS,

4.1.6. karta SIM GSM-R;

5. Podsystem tabor:

5.1. dla lokomotyw i wagonów pasażerskich:

5.1.1. pótsprzęg holowniczy do holowania i ratownictwa,

5.1.2. kota,

5.1.3. zabezpieczenie przeciwpoślizgowe kót (WSP),

5.1.4. światla czołowe,

5.1.5. światta sygnałowe,

5.1.6. światto końca pociagu,

5.1.7. sygnaty dźwiękowe,

5.1.8. odbierak pradu,

5.1.9. naktadki stykowe,

5.1.10. wytacznik szybki,

5.1.11. złacza do systemu opróżniania toalet,

5.1.12. przyłacze wlotowe do napetniania zbiorników wody; 
5.2. dla wagonów towarowych:

5.2.1. uktad biegowy,

5.2.2. zestaw kolowy,

5.2.3. koto,

5.2.4. oś,

5.2.5. oznaczenie sygnatowe końca pociagu;

5.3. dla wagonów pasażerskich $w$ aspekcie „Osoby o ograniczonej możliwości poruszania się"

5.3.1. kabiny toalet standardowe $i$ uniwersalne przystosowane dla osób niepetnosprawnych na wózkach inwalidzkich,

5.3.2. urzqdzenia do przekazywania informacji (dźwiękowych $i$ wizualnych) pasażerom,

5.3.3. urzqdzenia alarmowe dla pasażerów,

5.3.4. urzadzenia wspomagajace wsiadanie,

5.3.5. przyciski,

5.3.6. stanowiska przewijania dzieci,

5.3.7. oznakowanie wizualne i dotykowe.

Punkty otwarte odnoszące się do całej sieci oraz do kompatybilności technicznej między pojazdem i siecią wg $[2,3]$ są następujące (dla wagonów w prawej kolumnie):

\begin{tabular}{|c|c|c|c|}
\hline Element podysstemu, "Tabor" & Punkt niniejszej TSI & $\begin{array}{l}\text { Aspekt techniczany nieujegry } \\
\text { w nniniejzzej TSI }\end{array}$ & Uwagi \\
\hline $\begin{array}{l}\text { Wymagania szczególne } \\
\text { dotyczace taboru konwen- } \\
\text { cjonalnego umożliwiające } \\
\text { jego bezpieczną eksploa- } \\
\text { tacje w sieci kolei duzych } \\
\text { prędkości }\end{array}$ & 1.2 & Wszystkie wymagania & Kompatybilność z odnosną̧ siecią. \\
\hline 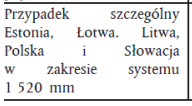 & 7.3 .2 & $\begin{array}{l}\begin{array}{l}\text { Wszystkie punkty } \\
\text { punkty otwarte }\end{array} \\
\text { TSI }\end{array}$ & $\begin{array}{l}\text { Punkt otwarty w celu wskazania, iż } \\
\text { konieczne są dalsze prace dotyczące } \\
\text { systemu } 1520 \text { mmm. }\end{array}$ \\
\hline Element podystemu „Tabor" & Punkt niniejzzej TSI & $\begin{array}{l}\text { Aspekt techniczny nieujety } \\
\text { w niniejszej TSI }\end{array}$ & Uwagi \\
\hline $\begin{array}{l}\text { Monitorowanie stanu } \\
\text { łoziysk osi }\end{array}$ & $\begin{array}{l}4.2 .3 .3 .2 \\
4.2 .3 .5 .2 .1\end{array}$ & $\begin{array}{l}\text { Zakres temperatury roboczej dla } \\
\text { urządzenia przytorowego }\end{array}$ & $\begin{array}{l}\text { Dopuszczalna wartóść temperatury } \\
\text { zapisana w dokumentacii tech- } \\
\text { nicznej. Do sprawdzenia kompaty- } \\
\text { bilność z odnośną siecią. }\end{array}$ \\
\hline $\begin{array}{l}\text { Dynamiczne zachowanie } \\
\text { ruchowe }\end{array}$ & 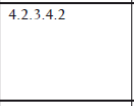 & 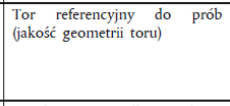 & $\begin{array}{l}\text { Protokół z preprowadzonego } \\
\text { badania zawiera opis warunków na } \\
\text { torze stużącym do prób. Do } \\
\text { zbadania w celu sprawdzenia } \\
\text { kompatybilności z odnośną siecią. } \\
\end{array}$ \\
\hline $\begin{array}{l}\text { Dynamiczne zachowanie } \\
\text { ruchowe }\end{array}$ & 4.2 .3 .4 .2 & $\begin{array}{l}\text { Kombinacja prędkości, krzy- } \\
\text { wizny, niedoboru przechylki } \\
\text { zgodnie z normą EN } 14363 .\end{array}$ & $\begin{array}{l}\text { Protokóf z przeprowadzonego } \\
\text { badania opis toru slużacego do } \\
\text { prob. Do zbadania w celu spraw- } \\
\text { dzenia kompatybilności z odnośną } \\
\text { siecią. }\end{array}$ \\
\hline $\begin{array}{l}\text { Zestawy kó́ - stożkowa- } \\
\text { tość ekwiwalentna }\end{array}$ & 4.2 .3 .4 .3 .2 & $\begin{array}{l}\text { Eksploatacyjna wartośś stożko- } \\
\text { watości ekwiwalentnej }\end{array}$ & $\begin{array}{l}\text { Do ustalenia kryteria utrzymania } \\
\text { w zależności od warunków danej } \\
\text { sieci. }\end{array}$ \\
\hline $\begin{array}{l}\text { Układ hamulcowy nieza- } \\
\text { leżny od warunków przy- } \\
\text { czeppości - wymagania } \\
\text { ogólne }\end{array}$ & 4.2 .4 .8 .3 & Szynowy hamulec wiroprądowy & 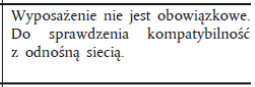 \\
\hline Opuszczanie pantografów & 4.2.2.2.2.9.10 & $\begin{array}{l}\text { Obowizzkower samoczynne } \\
\text { urzadzzenie opuszzzajagce (ADD) }\end{array}$ & $\begin{array}{l}\text { ADD akceptowane } \\
\text { w transeuropejskiej sieci kolei } \\
\text { konwencjonalnych; nie jest } \\
\text { powszechnie obowiązujące (przepis } \\
\text { krajowy). } \\
\end{array}$ \\
\hline
\end{tabular}

\begin{tabular}{|c|c|c|c|}
\hline Element podsystemu .Tabor" & Punkt & $\begin{array}{l}\text { Aspekt techniczny nieujerty w niniejszej } \\
\text { TSI }\end{array}$ & $\begin{array}{l}\text { Odniesienie do innyct } \\
\text { podystembiw w celut } \\
\text { uwzzglednienia punktu } \\
\text { otwartego }\end{array}$ \\
\hline Monitorowanie stanu fożysk osi & 4.2.3.4. & $\begin{array}{l}\text { Nieobowizzkowe } \\
\text { pokladowe }\end{array}$ & $\begin{array}{l}\text { Wyposazenie } \\
\text { nieobowiązkowe }\end{array}$ \\
\hline $\begin{array}{l}\text { Warunki badawcze dla badań toro- } \\
\text { wych, okreslone w wormie EN } \\
14363 \text {, nie zawsze sq w pelni } \\
\text { možliwe do osiagnnięcia }\end{array}$ & $\begin{array}{l}6.22 .2 .3 \\
(4.2 .3 .5 .2) \\
\end{array}$ & $\begin{array}{l}\text { Wháśiwości geonetrii toru oraz } \\
\text { kombinacie predkości, krzywizny, } \\
\text { niedoboru przechylki (pkt 5.4.2 } \\
\text { normy EN 14363) }\end{array}$ & \\
\hline $\begin{array}{l}\text { Zestawy kolowe ze zmiennym } \\
\text { rozstawem kól }\end{array}$ & 4.2 .3 .6 .6 & $\begin{array}{l}\text { Ocena dotycząca nasteppującego } \\
\text { wymogu: } \\
\text { system przestawiania zmiennego } \\
\text { zestawu kolowego gwarantuje } \\
\text { bezpieczne zaryglowanie w prawid- } \\
\text { lowej zanierzonej pozycji osi } \\
\text { danego kola oraz wszelkiego przy- } \\
\text { mocowanego wyposazenia hamul- } \\
\text { cowego. }\end{array}$ & \\
\hline $\begin{array}{l}\text { Kompozytowe klocki hanulcowe } \\
\text { w dodatku G }\end{array}$ & 7.1.2 C.14 & $\begin{array}{l}\text { Ocena przez jednostkę notyfiko- } \\
\text { waną }\end{array}$ & \\
\hline
\end{tabular}

Ponadto w TSI uwzględniono szereg szczegółowych punktów otwartych, które nie odnoszą się do kompatybilności technicznej pomiędzy pojazdem i siecią, np. szereg funkcji związanych z bezpieczeństwem.

Zakres wymaganych badań pojazdów kolejowych nie interoperacyjnych, z podziałem na:

a) pojazdy trakcyjne

b) wagony pasażerskie

c) wagony towarowe

d) pojazdy specjalne

przedstawione zostały w rozporządzeniu [4].

Zakresy badań są podobne, z niewielkimi zmianami wewnątrz niektórych punktów (np. 1.g), w stosunku do zapisanych w rozporządzeniu uchylonym (Dz. U. 2005, nr 212, poz. 1772), za wyjątkiem:

$\underline{\operatorname{ad} \text { a) }}$

z) sprawdzenie urzadzeń zewnętrznych pojazdu trakcyjnego, w tym:

- połaczeń międzywagonowych, mostków przejściowych $i$ watków gumowych,

- w zakresie malowania i napisów,

za) badanie urzqdzeń wewnętrznych zespołu trakcyjnego, wagonu silnikowego i innego pojazdu

kolejowego z napędem, przeznaczonego do przewozu osób, w tym:

- okien, drzwi czolowych,

- urzqdzeń sanitarnych, 
zb) badanie drzwi wejściowych zespołu trakcyjnego, wagonu silnikowego, innego pojazdu kolejowego z napędem, przeznaczonego do przewozu osób i autobusu szynowego,

zc) sprawdzenie odporności zespotu trakcyjnego, wagonu silnikowego, innego pojazdu kolejowego z napędem, przeznaczonego do przewozu osób i autobusu szynowego na trudne warunki

$\underline{\mathbf{a d} \mathbf{b}, \mathbf{b} \mathbf{i} \mathbf{d})}$ atmosferyczne zwiqzane z występowaniem ekstremalnych temperatur, śniegu, lodu i gradu

$z a / y / x)$ sprawdzenie odporności wagonu pasażerskiego / pojazdu specjalnego /pojazdu pomocniczego na trudne warunki atmosferyczne zwiqzane z występowaniem ekstremalnych temperatur, śniegu, lodu i gradu.

Zgodnie z $\S 3$ ust. 2 [5] składany do UTK wniosek powinien zawierać:

1) wyniki badań typu pojazdu kolejowego przeprowadzonych przez jednostke upoważniona;

2) dokumentacje techniczna, w tym:

a) warunki techniczne wykonania i odbioru,

b) dokumentacje techniczno-ruchowa,

c) porozumienie w sprawie wykonania prób eksploatacyjnych, którego wzór określa załqcznik nr 1 do rozporzadzenia wraz z ich programem - w przypadku nowych typów pojazdów kolejowych lub konieczności przeprowadzenia prób eksploatacyjnych

d) opinię techniczna wydana przez zarzadcę infrastruktury lub podmiot, o którym mowa $w$ art. 23 ust. 2 ustawy - w przypadku typów pojazdów kolejowych po przeprowadzonych próbach eksploatacyjnych,

e) opinie jednostki upoważnionej,

f) opinie Transportowego Dozoru Technicznego w zakresie urzqdzeń technicznych podlegajqcych dozorowi technicznemu.

Świadectwo może zostać przyznane na czas określony lub nieokreślony, wg zasad określonych w $§ 6$ [5].

1. Świadectwa, o których mowa w $\$ 2$ i 3, wydaje się na czas nieokreślony, a w przypadku nowych typów lub konieczności wykonania prób eksploatacyjnych, na czas określony - przewidziany na przeprowadzenie tych prób.

2. Próby, o których mowa w ust. 1, przeprowadza się zgodnie z programem prób eksploatacyjnych, opracowanym przez jednostke upoważniona i zatwierdzanym przez Prezesa UTK.

Załącznik 1 do [5] zawiera wzór porozumienia trójstronnego między użytkownikiem, producentem i jednostką. Nowością jest wprowadzenie zapisów wymagających określenia praw i obowiązków stron oraz zakres ich odpowiedzialności.

Link do krajowych aktów prawnych jest następujący:

http://www.utk.gov.pl/pl/akty-prawne/227,Akty-Prawne-obowiazujace-w-Urzedzie-TransportuKolejowego.html.

\section{Specyficzne wymagania w zakresie $O T M$}

Maszyny do prac torowych (Operational Track Machine) to pojazdy zaprojektowane specjalnie do celów budowy i utrzymania torów i infrastruktury. OTM używane są w różnych trybach: tryb pracy, tryb transportowy - pojazd z własnym napędem, tryb transportowy - pojazd ciągniony.

Pojazdy służące do kontroli infrastruktury wykorzystywane do monitorowania stanu infrastruktury uznaje się za OTM określone powyżej.

Stosowanie TSI [2] w odniesieniu do OTM (określonych w pkt 2.2 i 2.3) nie jest obowiązkowe.

Możliwe są trzy tryby procedur dopuszczenia do eksploatacji, każda z udziałem jednostki oceniającej.

Tryb 1: Wnioskodawca, zgodnie z TSI [2], pkt. 7.1.1.3, może na zasadzie dobrowolności przeprowadzić procedurę oceny zgodności wg pkt $6.2 .1 \mathrm{w}$ celu wystawienia deklaracji weryfikacji WE. Taka deklaracja powinna być uznana przez wszystkie kraje członkowskie.

Procedurę przeprowadza się wg wybranej kombinacji modułów.

Tryb 2: Wnioskodawca może nie ustanawiać deklaracji i uruchamia procedurę uzyskania zezwolenia w trybie opisanym w art. 24 lub 25 Dyrektywy 2008/57/WE (patrz rozdz. 1).

Tryb 3: W przypadku zmian nieznaczących wnioskodawca zobowiązany jest przeprowadzić analizę ryzyka wg Rozporządzenia Komisji WE (352/2009 z 24.4.09) i przekazać jednostce opiniującej do oceny. Obecnie może to być jednostka wewnętrzna wnioskodawcy lub zewnętrzna, spełniająca wymagania bezstronności i kompetencji, wybrana przez wnioskodawcę.

Zgodnie z Rozporządzeniem Wykonawczym nr 402/2013 z 30.4.2013 (art. 19) po 21.5.2015 jednostka zaangażowana w ocenę będzie musiała uzyskać uznanie lub akredytację.

W przypadku wprowadzenia zmian znaczących w konstrukcji pojazdu posiadającego świadectwo wymagane jest wystapienie do Prezesa UTK o wydanie nowego zezwolenia/świadectwa. 
Przepisy dotyczące wytrzymałości konstrukcyjnej OTM wymieniono w dodatku C, pkt C.1 [2], a dotyczące podnoszenia na linach i podnoszenia podnośnikiem określono w pkt C.2.

W przypadku OTM można stosować odmienne stany obciążenia (masa minimalna, masa maksymalna), aby uwzględnić opcjonalne urządzenia pokładowe.

W przypadku OTM dozwolone jest wykazanie bezpieczeństwa przed wykolejeniem podczas jazdy po wichrowatym torze za pomocą zatwierdzonej metody obliczeniowej. Jeżeli nie jest to możliwe, należy przeprowadzić próby zgodnie z wymaganiami ustalonymi w normie EN 14363:2005.

W przypadku jazdy po wichrowatym torze warunki testowe określone normą EN 14363:2005, pkt 4.1, mają zastosowanie do maszyn wyposażonych w wózki, jak również posiadających indywidualne zestawy kołowe.

Dynamiczne zachowanie podczas jazdy

Punkt 4.2.3.4.2 stosuje się do pojazdów kolejowych skonstruowanych dla prędkości powyżej $60 \mathrm{~km} / \mathrm{h}$. Nie stosuje się go do OTM (tabor kolejowy specjalny przeznaczony do budowy i utrzymania infrastruktury kolejowej); wymagania dotyczące OTM ustalono w dodatku C, pkt C.3.

Obliczenia dotyczace pojemności cieplnej

W przypadku OTM dopuszcza się sprawdzenie tego wymagania w drodze pomiarów temperatury kół i elementów hamulców.

W przypadku OTM, aby zapewnić widoczność niskich sygnalizatorów, dozwolone jest przechodzenie maszynisty do różnych miejsc w kabinie w celu spełnienia powyższego wymagania; spełnienie tego wymagania w pozycji siedzącej podczas prowadzenia pociągu nie jest wymagane.

OTM powinny spełniać wymagania określone w:

— TSI „Bezpieczeństwo w tunelach kolejowych” [15], pkt 4.2.5.1. „Właściwości materiałów konstrukcyjnych i wyposażeniowych pojazdów szynowych”, 4.2.5.6. „Pokładowe czujki pożarowe” i 4.2.5.7. „Środki łączności w pociagach”, oraz

— wymaganiach zawartych w niniejszej TSI, pkt 4.2.10.2 „Wymagania materiałowe” i 4.2.10.3 „Środki specjalne dotyczące płynów łatwopalnych”.

\section{Udzial jednostki w procesie oceny zgodności pojazdów}

Zakres prac jednostki notyfikowanej/uprawnionej jest zależny od wybranych przez wnioskodawcę zestawu modułów, wg zasad opisanych w [10]. Poniżej przedstawiono podstawowe, z punktu widzenia jednostki notyfikowanej, informacje o tych modułach.

a) Moduly CB/SB: Badanie typu WE

- Badanie typu WE to ta część procedury oceny zgodności, wedlug której jednostka notyfikowana bada rozwiazanie techniczne sktadnika interoperacyiności/podsystemu oraz weryfikuje i poświadcza, że rozwiqzanie to spetnia wymagania technicznej specyfikacji interoperacyjności (TSI) majace do niego zastosowanie.

- Producent sklada wniosek o badanie typu WE w wybranej przez siebie jednostce notyfikowanej.

- Badanie typu WE można przeprowadzić jednym z nastęujacych sposobów:

a) badanie egzemplarza próbnego sktadnika interoperacyjności/calego podsystemu reprezentatywnego dla przewidywanej produkcji (typ produkcji),

b) ocena adekwatności rozwiqzania technicznego sktadnika interoperacyjności poprzez zbadanie dokumentacji technicznej i dowodów potwierdzajacych, o których mowa w pkt 3, oraz zbadanie reprezentatywnych dla przewidywanej produkcji egzemplarzy próbnych jednej lub większej liczby części krytycznych sktadnika interoperacyjności (połaczenie typu produkcji i typu projektu),

c) ocena adekwatności rozwiqzania technicznego sktadnika interoperacyiności/podsystemu poprzez zbadanie dokumentacji technicznej i dowodów potwierdzajacych (w załacznikach do wniosku), bez badania egzemplarza próbnego (typ projektu).

Zawartość wniosku jest ściśle określona w [8] i obejmuje on m.in. pisemną deklarację, że ten sam wniosek nie został złożony w żadnej innej jednostce notyfikowanej oraz dokumentację techniczną. Jednostka bada dokumentację techniczną i dowody potwierdzające, weryfikuje egzemplarze próbne oraz przeprowadza badania i testy, po czym sporządza sprawozdanie z oceny, a jeśli wynik jest pozytywny wydaje certyfikat badania typu dla składnika/podsystemu.

b) Moduły CF/SF: Zgodność z typem/weryfikacja WE w oparciu o weryfikację produktu

- Zgodność z typem w oparciu o weryfikacje produktu to ta część procedury oceny zgodności, wedlug której producent wywiqzuje się z określonych zobowiqzań oraz zapewnia i deklaruje, na swoja wytacznq odpowiedzialność, że rozpatrywane skladniki interoperacyjności/podsystem, sq zgodne z typem opisanym $w$ certyfikacie badania typu WE i spetniaja wymagania technicznej specyfikacji interoperacyjności (TSI) majace do nich zastosowanie. 
- Wybrana przez producenta jednostka notyfikowana przeprowadza odpowiednie badania i testy w celu sprawdzenia zgodności składników interoperacyjności/podsystemu z zatwierdzonym typem opisanym w certyfikacie badania typu WE oraz z wymaganiami TSI. Dodatkowo dla podsystemu jednostka bada ważność certyfikatu badania typu WE.

- Wszystkie sktadniki interoperacyjności sq osobno badane i poddawane właściwym testom określonym $w$ stosownej TSI, normach zharmonizowanych lub specyfikacjach technicznych albo testom równoważny, $w$ celu zweryfikowania ich zgodności z zatwierdzonym typem opisanym $w$ certyfikacie badania typu WE oraz z wymaganiami TSI. W przypadku, gdy test nie jest określony w TSI, normach zharmonizowanych ani specyfikacjach technicznych, decyzja w sprawie wtaściwych testów, jakie maja zostać przeprowadzone, jest uzgadniana pomiędzy producentem i właściwa jednostkq notyfikowanq.

- Jednostka notyfikowana wydaje certyfikat zgodności WE w odniesieniu do przeprowadzonych badań i testów.

- Producent sporzadza pisemnq deklarację zgodności WE dla składnika interoperacyjności i przechowuje ja do dyspozycji organów krajowych.

c) Modut CV: Walidacja typu na podstawie badania eksploatacyjnego (przydatność do stosowania)

- Walidacja typu na podstawie badania eksploatacyjnego to ta część procedury oceny, w której jednostka notyfikowana stwierdza i poświadcza, że egzemplarz próbny, reprezentatywny dla przewidywanej produkcji, spetnia majqce do niego zastosowanie wymagania w zakresie przydatności do stosowania, określone w technicznej specyfikacji interoperacyjności (TSI).

- Producent składa wniosek o walidacje typu na podstawie badania eksploatacyjnego w wybranej przez siebie jednostce notyfikowanej.

- Jednostka bada dokumentację $i$ weryfikuje program walidacji, weryfikuje reprezentatywność typu, monitoruje eksploatację oraz ocenia sprawozdania wydawane przez przedsiębiorstwa.

- Jeżeli typ spetnia wymagania TSI majace zastosowanie do rozpatrywanego sktadnika interoperacyjności, jednostka notyfikowana wydaje producentowi certyfikat przydatności do stosowania WE.

W odniesieniu do wszystkich modułów obowiązują poniższe, jednakowe zasady:

- każda jednostka notyfikowana informuje odnośne organy notyfikujace o certyfikatach $i$ wszelkich dodatkach do niech, które wydała lub cofnęta.

- każda jednostka notyfikowana informuje pozostate jednostki notyfikowane o certyfikatach, których wydania odmówita, które cofnęła, zawiesiła lub poddała innym ograniczeniom, a także, na żadanie, o certyfikatach $i$ wszelkich dodatkach do nich, które wydata.

\section{Podsumowanie}

W artykule przedstawiono podstawowe zasady obowiązujące w trybie oceny zgodności podsystemu tabor i jego składników interoperacyjności. Autor ograniczył rozważania do pojazdów niezgodnych z wszystkimi TSI, bowiem takie są traktowane jako niezgodne z TSI.

Zasady obowiązujące dla weryfikacji związanej z TSI „Sterowanie” [12] na zgodność z ETCS (European Train Control System) zostaną przedstawione po zaistnieniu możliwości badania i weryfikacji pojazdów trakcyjnych na szlakach PKP PLK.

Należy pamiętać, że oprócz wymagań zawartych w omówionych TSI $[2,3]$ należy wziąć pod uwagę pozostałe TSI, mające powiązanie z pojazdami kolejowymi [12:15].

Istotnym elementem unijnej legislacji w sprawie interoperacyjności jest decyzja [16] i wydany na jej podstawie dokument referencyjny [17], zawierający wytyczne dotyczące stosowania przepisów związanych z interoperacyjnością. Pomocnym dokumentem jest także przewodnik stosowania TSI [18].

Link do tekstów wytycznych i przewodników jest następujący:

http://www.utk.gov.pl/pl/wymagania-wspolnotowe/wytyczne-i-przewodniki/129,Kluczowe-

dokumenty-pozalegislacyjne.html

W kolejnych numerach kwartalnika „Pojazdy Szynowe” zostaną opublikowane następne artykuły z serii „Prawne regulacje w zakresie taboru kolejowego”:

- Ocena zgodności podsystemu „Sterowanie - urządzenia pokładowe” i jego składników interoperacyjności

- Ocena bezpieczeństwa podsystemu „Tabor” w zakresie wyceny i oceny ryzyka. 


\section{Obowiązujące dokumenty}

[1] Dyrektywa Parlamentu Europejskiego i Rady 2008/57/WE z dnia 17 czerwca 2008 r. w sprawie interoperacyjności systemu kolei we Wspólnocie

[2] Decyzja Komisji z dnia 18 listopada 2014 r. w sprawie technicznej specyfikacji interoperacyjności odnoszacej się do podsystemu „,Tabor - lokomotywy i tabor pasażerski” systemu kolei w Unii Europejskiej

[3] Rozporzqdzenie Komisji (UE) nr 321/2013 z dnia 13 marca 2013 r. dotyczqce technicznej specyfikacji interoperacyjności odnoszacej się do podsystemu „Tabor - wagony towarowe” systemu kolei w Unii Europejskiej i uchylajace decyzję 2006/861/WE

[4] Rozporzqdzenie Ministra Transportu, Budownictwa i Gospodarki Morskiej z dnia 7 sierpnia 2012 r. w sprawie zakresu badań koniecznych do uzyskania świadectwa dopuszczenia do eksploatacji typu budowli przeznaczonej do prowadzenia ruchu kolejowego, świadectwa dopuszczenia do eksploatacji typu urzqdzenia przeznaczonego do prowadzenia ruchu kolejowego oraz świadectwa dopuszczenia do eksploatacji typu pojazdu kolejowego (Dz. U. poz. 918)

[5] Rozporzqdzenie Ministra Transportu, Budownictwa i Gospodarki Morskiej z dnia 10 sierpnia 2012 r. w sprawie świadectw dopuszczenia do eksploatacji typu (Dz. U. poz. 919)

[6] Rozporzadzenie Ministra Transportu, Budownictwa i Gospodarki Morskiej z dnia 27 grudnia 2012 r. w sprawie wykazu właściwych krajowych specyfikacji technicznych i dokumentów normalizacyjnych, których zastosowanie umożliwia spetnienie zasadniczych wymagań dotyczqcych interoperacyjności systemu kolei (Dz. U. 2013 poz. 43)

[7] Rozporzadzenie Ministra Transportu, Budownictwa i Gospodarki Morskiej z dnia 6 listopada 2013 r. w sprawie interoperacyjności kolei (Dz. U. 2013 poz. 1297)

[8] Decyzja Komisji w sprawie modulów procedur oceny zgodności, przydatności do stosowania $i$ weryfikacji WE stosowanych $w$ technicznych specyfikacjach interoperacyjności przyjętych na mocy dyrektywy Parlamentu Europejskiego i Rady 2008/57/WE (2010/713/UE).

[9] Ustawa z dnia 28 marca 2003 r. o transporcie kolejowym (Dz. U. 2003 nr 86 poz. 789)

[10] Durzyński Z.: Prawne regulacje w zakresie systemu kolei. Akredytacja, autoryzacja i notyfikacja jednostek certyfikujących i laboratoriów badawczych. Pojazdy Szynowe nr 1/2015

[11] Durzyński Z.: Prawne regulacje w zakresie systemu kolei. Unijne i krajowe przepisy dotyczące taboru kolejowego. Pojazdy Szynowe nr 4/2014

[12] Decyzja Komisji (UE) 2015/14 z dnia 5 stycznia 2015 r. zmieniajaca decyzje 2012/88/UE w sprawie technicznej specyfikacji interoperacyjności w zakresie podsystemów „Sterowanie” transeuropejskiego systemu kolei

[13] Rozporzadzenie Komisji (UE) nr 1304/2014 z dnia 26 listopada 2014 r. w sprawie technicznych specyfikacji interoperacyjności podsystemu "Tabor kolejowy - hałas", zmieniajace decyzje 2008/232/WE i uchylajaca decyzję 2011/229/UE

[14] Rozporzqdzenie Komisji (UE) nr 1300/2014 z dnia 18 listopada 2014 r. w sprawie technicznych specyfikacji interoperacyjności odnoszacych się do dostępności systemu kolei Unii dla osób niepetnosprawnych i osób o ograniczonej możliwości poruszania się

[15] Rozporzqdzenie Komisji (UE) nr 1303/2014 z dnia 18 listopada 2014 r. w sprawie technicznych specyfikacji interoperacyjności w zakresie aspektu "Bezpieczeństwo w tunelach kolejowych" systemu kolei

[16] Decyzja Komisji z dnia 9 marca 2011 r. w sprawie publikacji dokumentu referencyjnego i administrowania dokumentem referencyjnym, o którym mowa w art. 27 ust. 4 dyrektywy Parlamentu Europejskiego i Rady 2008/57/WE w sprawie interoperacyjności systemu kolei we Wspólnocie. (2011/155/UE)

[17] Część 1 dokumentu referencyjnego przewidzianego $w$ art. 27 dyrektywy w sprawie interoperacyjności kolei. Wytyczne dotyczqce stosowania. Europejska Agencja Kolejowa. 22.07.2013

[18] Przewodnik stosowania technicznych specyfikacji interoperacyjności (TSI) zgodnie z mandatem ramowym C(2007)3371. Wersja ostateczna $z$ dnia 13.07.2007 r. ERA/GUI/07-2011/INT. Wersja 1.02. 30.11 .2012 